\title{
ILLOCUTIONARY ACTS FOUND IN RACHEL'S UTTERANCES: THE MAIN CHARACTER OF I AM NOT ASHAMED MOVIE
}

\author{
Gabriella Samantha Valerian', ${ }^{1}$,ujana ${ }^{2}$ \\ ${ }^{1,2}$ Gunadarma University, Jl. Margonda Raya No. 100, Depok 16424, Jawa Barat \\ Corresponding Author(S): gabyvalerian@gmail.com
}

\begin{abstract}
:
This article aims to identify the types and functions of illocutionary acts in the main character's utterances in "I Am Not Ashamed" movie. The theory used in this article is theory of illocutionary acts proposed by Searle (1976) who classified the types of illocutionary acts into five types, there are representatives, directives, commissives, expressives, and declaratives. The method in this article using a qualitative descriptive method which used the main character's dialogue of the movie I Am Not Ashamed, to be a data for this research. The result of this study is to make a good understanding about illocutionary acts especially representatives, directives, commissives, and expressives which found in this research, because when we are communicating with others, unconsciously the sentences that we say has an intended meaning and that can cause a misunderstanding. Hence, through this research, the readers can understand about illocutionary acts and prevent the misunderstanding in communicating.
\end{abstract}

Keywords:

Speech acts, illocutionary acts, $I$ Am Not Ashamed Movie

\section{INTRODUCTION}

In communicating with others, we are not just uttered it, but also have a certain actions in our utterances. In pragmatics, people who are not just saying a words but also doing something is called speech act.

Speech Act has three classifications there are locutionary acts, illocutionary acts, and perlocutionary acts. Illocutionary acts is the act of doing something, when the sentences uttered by the speaker, it has the intended meaning. There are five classifications to classify the function of speech acts by John. R. Searle (1979), there are, declaratives, representatives, commisives, directives, and expressives. In this research, researcher wants to analyze illocutionary acts from a movie, There are many types of movies that can be a good object to analyze the illocutionary acts. Researcher interested to analyzed the movie entitled "I Am not Ashamed".

The motivation of the researcher to choose this topic is to convey to the reader that we can find many intended meanings that uttered by the characters in this movie, and researcher choose "I Am not Ashamed" movie because this movie has not analyzed yet 
by other researcher. This movie also have a good values of life and remind us for always pray and grow in our faith.

A British Philosopher of language J.L Austin who developed Speech Act Theory. J.L Austin claims that to say something is to do something. Sentences are neither a description nor a statement of an act, but actually doing the act itself. Speech acts is a study of how people act or perform an action when making an utterance. Speech acts often takes place in verbal and nonverbal communcation.

J. L. Austin distinguised an act into 3, those are locutionary act, illocutionary act and perlocutionary act (Austin, 1962). These are the 3 acts based on J.L Austin:

\section{Locutionary Act}

Locutionary act is considered as the act of saying something. It is the literal meaning or semantic meaning which uttered by the speaker. Cutting (2002:16) states that locutionary is what is said. (Hidayat, 2016). Based on Cutting in Hidayat's journal, it can be conclude that locutionary act is the act which happened based on what the speaker said without any other meaning in the speaker's utterance. According to (Yule, 1996, p. 48), locutionary act is the basic act of utterance or producing a meaningful linguistic expression. Based on Yule, it can be conclude that locutionary act is the actual/literal meaning of what the speaker say to the hearer. These are some examples of locutionary act: (1) I'm thirsty, (2) This room is so hot.

\section{Illcutionary Act}

Illocutionary act is considered as the act of doing something. In illocutionary act, when speaker uttered something, speaker also has an action in their utterance and there is an intended meaning in the speaker's utterance, so the hearer should find out the meaning of the speaker's utterance. According to (Cruse, 2000), illocutionary acts are acts which are internal to the locutionary act, in the sense that, if the contextual condition are appropriate, once the locutionary act has been performed, so has the illocutionary act. Based on Cruse, it can be conclude that illocutionary act is connected with locutionary act, if the locutionary performed with contextual condition, illocutionary can be happened. In Searle's theory (1976) of Illocutionary act, it consists of representatives, directives, commissives, expressives and declaratives. These are several examples of illocutionary acts: (1) I'm not hungry. (in fact, he/she was hungry but he/she doesn't have any money so he/she can't buy a food to eat.), (2) This bag is so cute. (this can has another meaning that is to ask the hearer to buy the bag for the speaker.)

\section{Perlocutionary Act}

Perlocutionary act is an effect of the utterance that uttered by the speaker. It is the act of affecting someone.

As Austin said in his book, it can be conclude that perlocutionary act is the consequences that speaker achieved from uttering something. This consequences that achieved by the speaker can be great or less or may be unintentional.

Based on Austin, it can be conclude that perlocutionary act is the result that achieved by the speaker which based on the speaker's utterances. The result from the utterances may 
be great or less. These are the examples of perlocutionary act: (1) Close the window. (the hearer will close the window.). (2) Clean your bedroom! (the hearer will clean the bedroom.)

In illocutionary act, there are five classifications of illocutionary act based on Searle (1976), such as:

1. Representatives

This act is the utterance that believed to be true by the speaker. The classes of representatives assessed with true or false. It commits the speaker to the truth of the expressed proposition, and expressed the speaker's belief. For example , "My cake is so delicious." It represents the speaker's opinion about a cake which the speaker made. But, the hearer can has another opinion about the speaker's cake.

2. Directives

This act has an aimed to make the hearer to do something as what the speaker said. The performative verbs of directives, such as : requesting, demanding, questioning, asking, proposing, advising, suggesting, interrogating, urging, encouraging, inviting, begging, ordering, etc. For example, "Close the door." when the speaker uttered it, the hearer will do some action that is closing the door.

3. Commissives

This act is to commit the speaker to some future action. The performative verbs of commissives, such as : ask, order, promising, beg, pledge, dare, challenge, threatening, offering, planning, pray, etc. For example, "I'll eat your cake later." It represent the speaker's promise that he/she will eat the cake.

4. Expressives

This act is to express the psychological state in the sincerity condition. In expressives, the speaker uttered what they feel to the hearer about the situation. The performative verbs of expressives, such as : congratulate, sad, happy, joy, thank, apologizing, worried, welcoming, regretting, surprised, fear, praise, greet, curious, etc. For example, "Thank you for the gift." It represent the speaker's expression that is thank his/her friend for the gift.

5. Declarations

This act has a special position because when the speaker uttered something, it can change the hearer's world or the hearer's condition. So, in declaratives, the speaker should have a special role in an institution. For example, "You're fired!" it can be uttered by boss in a company, the speaker which is a boss has a special position in the company and when the boss uttered that, the boss can change the hearer status from the employee into jobless.

\section{METHOD}

In conducting this research, researcher used a qualitative method to analyze the data. Generally, the data that we collected in qualitative research both in the form of words and pictures not in the form of numbers. Researcher used qualitative research to conduct the research because researcher analyze and describe the types and functions of illocutionary acts in the main character's utterance in "I Am Not Ashamed" movie.

In this research, researcher did several steps for collecting the data, there are, watching and comprehend every utterances that uttered by the main character in I Am Not Ashamed movie, paying attention to every main character's utterances in the movie, get the movie 
script from the internet to help researcher to find the types and functions in I Am Not Ashamed movie, watching back the movie while reading the scripts and underlined every utterances that uttered by the main character, rewrite all the utterances by the main character which has been underlined. This research used document technique to conduct the research.

Furthermore, In this research, researcher do several steps for analyzing the data. There are analyzing the main character's utterances in I Am Not Ashamed movie to find out the types of illocutionary acts using a theory proposed by Searle (1976), presenting all the utterances that uttered by the main character based on the types of illocutionary acts in a table, analyzing functions of illocutionary acts from the main character's utterances based on each types of illocutionary acts, classifying the main character's utterances that included into the types

\section{RESULTS AND DISCUSSION}

The data used in this research is based on the main character's utterances in "I Am Not Ashamed" movie which contain illocutionary acts. Researcher classified the main character's utterances in "I Am Not Ashamed" movie into the types and functions of illocutionary acts based on the theory of illocutionary acts proposed by Searle (1976).

Table 1 Types of Illocutionary Acts

\begin{tabular}{lcc}
\hline & Types of Illocutionary Acts & Amount of Data \\
\hline Representatives & & 123 \\
Directives & & 35 \\
Commissives & & 24 \\
Expressives & Total & 58 \\
& & 240 \\
\hline
\end{tabular}

Source: Types of illocutionary acts used in I Am Not Ashamed movie

There are two hundreds and forty data utterances that reseracher found and analyzed. It consists of the types of illcutionary acts and the functions of illocutionary acts. The types and the functions of illocutionary acts will be discuss in the table below. From the table above, it can be seen that there are four types of illocutionary acts which found in the main character's utterances of I Am Not Ashamed movie along with the amount of data for each types of illocutionary acts. It consists of representatives which had 123 data, directives had 35 data, commissives had 24 data, and expressives had 58 data, which found from watching and analyzing the data from the main character's utterances in I Am Not Ashamed movie.

Table 2. Functions of Illocutionary Acts

\begin{tabular}{clc}
\hline \multicolumn{1}{c}{ Types of Illocutionary Acts } & \multicolumn{1}{c}{ Functions of Illocutionary Acts } & Amount of Data \\
\hline & a. Describing & 6 \\
& b. Stating & 19 \\
c. Inform & 13 \\
d. Assert & 9 \\
& e.Claim & 10 \\
fepresentatives & f. Believe & 11 \\
& g. Conclude & 6 \\
h. Tell & \multicolumn{2}{c}{18} \\
& i. Agree & 7 \\
& j. Guess & 4 \\
& k. Assure & 4 \\
& 1. Remind & 15 \\
& & 5
\end{tabular}




\begin{tabular}{|c|c|c|}
\hline & a. Urging & 2 \\
\hline & b. Forbiding & 2 \\
\hline & c. Ask & 8 \\
\hline & d. Requesting & 8 \\
\hline Directives & e. Begging & 5 \\
\hline & f. Questioning & 3 \\
\hline & g. Inviting & 4 \\
\hline & h. Suggesting & 2 \\
\hline & i. Warning & 1 \\
\hline & a. Promising & 12 \\
\hline Commissives & b. Planning & 9 \\
\hline Commissives & c. Offering & 1 \\
\hline & d. Threatening & 2 \\
\hline & a. Surprise & 6 \\
\hline & b. Thank & 10 \\
\hline & c. Apology & 5 \\
\hline & d. Annoyed & 2 \\
\hline & e. Curious & 15 \\
\hline Expressives & f. Greet & 4 \\
\hline & g. Disappointment & 2 \\
\hline & h. Worried & 3 \\
\hline & i. Like & 2 \\
\hline & j. Satisfied & 6 \\
\hline & k. Praise & 3 \\
\hline Total & 36 & 240 \\
\hline
\end{tabular}

Source: Functions of Illocutionary Acts used in I Am Not Ashamed movie

From the table above, it can be seen that there are the types of illocutionary acts followed by the functions and the amount of data for each functions. Researcher found 36 data of functions of illocutionary acts in the main character's utterances of I Am Not Ashamed movie.

In table 2 there is types of illocutionary acts Representatives which performed by Rachel the main character of I Am Not Ashamed movie, along with functions of illocutionary acts such as, describing, stating, inform, assert, claim, believe, conclude, tell, agree, guess, assure and remind. Based on the data finding, stating is the functions of illocutionary acts that frequently used by the main character with 19 utterances, and the least used is guess with 4 data.

Next types of illocutionary acts are directives were also produced by Rachel the main character of I Am Not Ashamed movie, along with functions of illocutionary acts such as, urging, forbiding, ask, requesting, begging, questioning, inviting, suggesting, and warning. Ask and requesting are the functions that dominant used in directives with 8 data and the least used is warning with 1 data

While for commissives also the types of illocutionary acts that used by the main character along with the functions of illocutionary acts such as, promising, planning, offering and threatening. Promising is the functions which frequently used in commissive with 12 data and the least used in functions of illocutionary acts is offering with 1 data.

And last, for expressives the types of illocutionary acts which used by the main character along with functions of illocutionary acts such as, surprise, thank, apology, annoyed, curious, greet, disappointment, worried, like, satisfied and praise. The functions of illocutionary acts that dominant used in expressive is curious with 15 data and the least 
used of functions of illocutionary acts are annoyed, disappointment and like with 2 data. The types and functions of illocutionary acts as explained above can be seen from the data below:

\section{Representatives}

\section{Data 1}

"It's like...I have a heavy heart and this burden on my back."

This utterance is one of the scene in "I Am Not Ashamed" movie which uttered by Rachel the main character. This utterance above included as representatives because Rachel is describing what she felt that time and she believed all the things that happened to her is like she have a heavy heart and that's burden on her back. Hence, The function of illocutionary acts used in this utterance is describing.

\section{Data 2}

"My work here is done."

This utterance is included into representatives because Rachel is proving that she can make her step father smile after forcing him to let her own a car. Hence, the function of illocutionary acts in this utterance is claim.

\section{Directives}

\section{Data 3}

“Craig! Come on, let's go!”

This utterance is one of the scene in "I Am Not Ashamed" movie which uttered by Rachel the main character. This utterance can be included as directives because Rachel is urging her brother to get ready immediately because they are going to be late to go to school if her brother doesn't getting ready immediately. The functions of illocutionary act in this utterance is urging.

\section{Data 4}

"Yeah... close your eyes."

This utterance can be included as directives because Rachel ask Nathan to close his eyes before Rachel give him a gift. After Nathan hear that utterance Nathan will do as what Rachel say. Hence, the function of illocutionary acts in this utterance is ask.

\section{Commissives}

\section{Data 5}

"I'll be right back."

This utterance indicates that Rachel commits to do some action in the future that is she will come back to her sister and go home. Hence, the function of illocutionary acts in this utterance is promising.

\section{Data 6}

"If you don't, I'll come find you." 
This utterance included as commissives because This indicates Rachel's future action if Nathan doesn't do what Rachel ask for. Hence, the function of illocutionary acts in this utterance is threatening.

\section{Expressives}

Data 7

"You scared me."

This utterance included as expressives because Rachel shows her expression that is surprised. When Nathan suddenly called her name, she surprised. Hence, the function of illocutionary acts in this utterance is surprise.

\section{Data 8}

"Thank you, guys."

This utterance included as expressives because Rachel is so thankful to her family at that time because her family were celebrating her birthday and gave her a gift. Hence, the function of illocutionary acts in this utterance is thank

\section{CONCLUSION}

According to the analysis, there are, analyzing the main character's utterances in I Am Not Ashamed movie to find out the types of illocutionary acts using a theory proposed by Searle (1976), presenting all the utterances that uttered by the main character based on the types of illocutionary acts in a table, analyzing functions of illocutionary acts from the main character's utterances based on each types of illocutionary acts, classifying the main character's utterances that included into the types, researcher found four types of illocutionary acts based on Searle that uttered by Rachel, the main character in I Am Not Ashamed movie, there are representatives, directives, commissives, and expressives. In the other hand, there are thirty six functions of illocutionary acts, such as describing, stating, inform, assert, claim, believe, conclude, tell, agree, guess, assure, remind, urging, forbiding, ask, requesting, begging, questioning, inviting, suggesting, warning, promising, planning, offering, threatening, surprise, thank, apology, annoyed, curious, greet, disappointment, worried, like, satisfied, and praise. For further researcher who wants to conduct the same topic, this study hoped to be a reference for conduct the study in the topic, especially in study of illocutionary acts.

\section{REFERENCE}

Baugh, B. (Director). (2016). I am not ashamed [Motion Picture].

Haucsa, G. M., Marzuki, A. G., Alek, \& Hidayat, D. N. (2020). Illocutionary speech acts analysis in tom cruise's interview. Academic Journal Perspective: Education, Language, And Literature.

Hidayat, A. (2016). Speech acts: Force behind words . English Education: Jurnal Tadris Bahasa Inggris.

Hornby. (2006). Oxford advanced learner's dictionary of current english. Uk: Oxford University Press.

Icong. (2011). Retrieved from schoolash: Http://Schoolash.Blogspot.Com/2011/12/ Definition-Language-According-To.Html 
Mardiane, D. R. (2020). Illocutionary act found in the main character's utterances in 1917 movie. Jakarta: Gunadarma University.

Mason, J. (2002). Qualitative researching 2nd edition. London: Sagepublications.

Nugroho, A. S. (2011). An analysis of illocutionary acts in sherlock holmes movie. Jakarta: State Islamic University Syarif Hidayatullah .

Rahayu, F. N., Arifin, M. B., \& Ariani, S. (2018). Illocutionary act in the main character's utterances in mirror mirror movie. Jurnal Ilmu Budaya.

Ramayanti, D., \& Marlina, L. (2018). The analysis of types illocutionary acts in "Tangled" Movie. E-Journal Of English Language \& Literature.

Rohma, N. (2008). Illocutionary acts used by characters in the man with the heart in the highlands William Saroyan's. Malang: The State Islamic University Of Malang.

Saputro, E. P. (2015). The analysis of illocutionary acts of jokowi's speeches. Yogyakarta: Sanata Dharma University.

Sbisà, M. (2007). How to read austin. Pragmatics.

Senft, G. (2014). Understanding pragmatics. New York: British Library Cataloguing In Publication Data.

Siddiqui, A. (2018). The principle features of English pragmatics in applied linguistics. Advances In Language And Literary Studies, 78.

Simbolon, R. (N.D.). An analysis of illocutionary acts in new moon movie.

Skillsyouneed. (N.D.). Retrieved from skillsyouneed: Https://Www.Skillsyouneed. Com/Ips/What-Is-Communication.Html

Slotta, J. (N.D.). Pragmatics. University Of Texas.

Smith, P. W. (1991). Speech act theory, discourse structure and indirect speech acts. The University Of Leeds Department Of Philosophy.

Suryati, S. D. (2018). An analysis of educational values in "Life Of Pi" movie. Lampung: Raden Intan State Islamic University.

Thoene, B. (N.D.). Scripts.Com. Retrieved From Scripts.Com: Https://Www.Scripts.Com/Script-Pdf/10552

Usman, F. R. (2017). An analysis of illocutionary acts in Donald Trump's Presidential Candidacy Speech. Makassar: Hasanuddin University .

Violeta, R. (2019). Speech acts analysis of the main character in maleficent movie script by Jane Mctee. Lampung: University Of Islamic State Raden Intan .

Wardani, N. A. (2011). An analysis of illocutionary act in prince of Persia: The sand of time movie. Jakarta: State Islamic University "Syarif Hidayatullah". 